\title{
First Conference of African Museums
}

THE Livingstone Museum is organizing the First Conference of African Museums as a first step towards a close and permanent co-operation between the Museums of Africa. The Conference will be held in Livingstone from Monday, 17 July, to Sunday, 23 July 1972. The theme will be 'Museums in Developing Africa', which will provide for a very wide range of possible contributions and enable participants to become acquainted with the specific needs and problems of other Museums. The Conference will be divided into the following sections: (1) Museum and research. (2) The role of the Museum in the conservation of the cultural heritage. (3) Educational role and extra-mural programme of the Museum. (4) Technical aspects of museological work in African countries: (a) preparation and building of Museum galleries; (b) organization of temporary exhibitions; (c) organization of moving exhibitions and special school exhibitions; $(d)$ mobile Museums.

Further details may be obtained from the Secretary of the Conference, P.O. Box RW. 546, Lusaka, Zambia.

\section{Second World Festival of Negro Arts: Nigeria 1974}

THE Nigerian government has approved, in principle, the holding in the later part of 1974 of a festival of Negro Arts in Lagos. Chief Enaharo, Commissioner for Information, has been appointed Commissioner for the festival and a national organization will be set up shortly to co-operate with the International Committee.

\section{University of Ife, Institute of African Studies: Appointment of Director}

CHIEF Ulir Beier has been appointed to succeed Professor Michael Crowder as Director of the Institute of African Studies at the University of Ife, on the latter's appointment as Professor at Abdullahi Bayero College of Ahmadu Bello University in Kano. Chief Beier, who is well known as the author of many books and articles on African art, was responsible for founding the Mbari club in Ibadan and the journal Black Orpheus, and for the development of the Oshogbo school of painters and craftsmen.

\section{Makerere University, Kampala: Makerere Institute of Social Research}

THIS Institute, founded in 1950, is the oldest social science research centre in East Africa, with a large collection of publications made over a period of twenty years. Research is concentrated on the disciplines of sociology, political science and public administration, economics, rural economy, and social work and social administration. The Institute aims to supply data and other information to government and academic institutions to facilitate planning for the development of the area and to co-ordinate research with other research centres in and outside Africa. A research programme on plan formulation and implementation for the development of rural and urban areas in Uganda is at present being undertaken in collaboration with the Uganda government by research workers from within and outside Africa. A two-day workshop on Research Priorities in Social Sciences in Uganda was held from 9 to ro July 1971, sponsored by the National Research Council and the Makerere Institute of Social Research. Copies of the report on this workshop may be obtained from the Institute, P.O. Box 16022, Kampala, Uganda.

\section{Université de Kisangani: Centre d'études des sciences humaines}

THE Centre d'études des sciences humaines (B.P. 2012, Kisangani: Director, Luis Beltrán) was founded in March 1970 as a result of the reorganization of the Centre d'etudes économiques et sociales under whose auspices a number of research projects, including the 
preparation of a demographic census of Kisangani, were carried out from 1968 to 1970 . In May 1970 the field of the new centre was broadened to include not only economics and the social sciences but also philosophy and arts, psychology, education, and theology. Under its new title, the centre has established the following sections: anthropology, linguistics, economics, political science, sociology, and further sections are to be added. The centre publishes the Revue congolaise des sciences humaines which has appeared twice yearly, in July and January, since July r 970.

\section{University College of Cape Coast, Ghana}

The University College of Cape Coast, established in 1967 with the primary aim of producing graduate teachers in arts and science subjects, became a full university in October $197 \mathrm{I}$. All students are required to undertake a one-yeat course in African studies. The co-ordinator of this course is Dr. Brookman-Amissah of the Department of Education. The question of whether an Institute of African Studies is to be established is being discussed. The Social Studies Project, sponsored jointly by the University and the Institute of Social Studies at The Hague, conducts research in the social sciences (with emphasis on economics, geography, history, and sociology) and assists research projects being undertaken by members of teaching departments. The results of research are published in a Research Report Series.

\section{Centre fédéral linguistique et culturel, Yaoundé}

The Centre fédéral linguistique et culturel (Director, Father E. Mveng) at Yaoundé was founded by UNESCO after the union of east and west Cameroun to assist in the promotion of bilingualism. Today it is attached to the Direction des affaires culturelles of the Ministry of Education. It has two sections, one concerned with the teaching of English and French, the other a cultural section, whose director is M. Eldridge Mohammadou, and which itself divides into two groups: research and animation culturelle. Under the latter heading, the Institute has organized a National Dance Ensemble, which performs traditional dances and develops new ones, has established a taped music archive, and has been working on theatre and the film. The research group has been concerned primarily with the collection of oral tradition-' the tackling of history, of sociology, of literature, through the oral traditions of the tribes concerned'. Studies made so far concern the Fulani, the Grassfield tribes, and the Beti-Fang. The section publishes in conjunction with the UNESCO centre at Niamey.

\section{The Institute of Linguistics}

THE Institute of Linguistics was formerly the West African branch of the Summer Institute (U.S.A.; also known as the Wycliffe Bible Translators). The Institute's headquarters are in Zaria (P.O. Box 489); the director for West Africa is Dr. John Bendor-Samuel and for Nigeria Dr. Ronald Stanford. Branches have been established in the Ivory Coast (B.P. 8949, Abidjan-Cocody, Director, Dr. Donald Webster) and in Ghana (P.O. Box 378, Tamale, Director, Dr. R. Rowland) and the establishment of a branch in Cameroun is foreseen. The Institute is primarily concerned with Bible translation, but has also carried out a great deal of basic linguistic research, mainly in minority languages in which little is written or which have not previously been reduced to writing. Fellows go to their chosen field for a period of about twelve years, during which time they are expected to learn the language and prepare a basic primer in it, translate the Gospels into it, and provide literacy and other materials for the local population. There are at present about fifty workers in the field, some of them trained linguists, others technicians working under the supervision of linguists, undertaking research in nearly thirty languages. In the summer of 1971 the Institute ran a vacation course at Ahmadu Bello University, offering training in linguistics and in translation. 